\title{
Association of modified cytosines and the methylated DNA-binding protein MeCP2 with distinctive structural domains of lampbrush chromatin
}

\author{
Garry T Morgan ${ }^{1}$, Peter L Jones ${ }^{2}$, Michel Bellini ${ }^{3^{*}}$ \\ From Epigenetics and Chromatin: Interactions and processes \\ Boston, MA, USA. 11-13 March 2013
}

The lampbrush chromosomes (LBCs) of the amphibian oocyte are the largest known chromosomes and offer the unique opportunity to visualize the distinctive closed and open chromatin structural domains with an unprecedented spatial resolution. In this study we investigated the association of DNA methylation and proteins interpreting methylation state, such as MeCP2, with LBCs. We expressed HA-tagged MeCP2 in Xenopus laevis oocytes, and we observed that while it predominantly targeted the transcriptionally inactive chromomeres, a minor fraction of HA-MeCP2 also associated with many of the transcriptionally active lateral loops of LBCs. We further demonstrated that the association of MeCP2 with LBCs is directly determined by its 5 -methylcytosine-binding domain. We then defined the distribution of 5-methylcytosines $(5 \mathrm{mC})$ by immunostaining Хепориs and axolotl LBCs and confirmed the pattern suggested by the expression of $\mathrm{HA}-\mathrm{MeCP} 2$ targeting of intense staining of the chromomeres and of many loop bases. In addition, we found that short interstitial regions of the active transcriptional units could be clearly stained for $5 \mathrm{mC}$. Interestingly, these $5 \mathrm{mC}$-positive regions corresponded precisely to segments of active transcription units from which RNA polymerase II and nascent transcripts were simultaneously absent. Together, these data support a model presenting MeCP2 as both a transcriptional repressor and activator.

${ }^{3}$ Department of Cell and Developmental Biology, University of Illinois, $601 \mathrm{~S}$. Goodwin Avenue, Urbana, IL 61801, USA

Full list of author information is available at the end of the article
Author details

${ }^{1}$ Centre for Genetics and Genomics, School of Biology, University of Nottingham, Queens Medical Centre, Nottingham NG72UH, UK. ${ }^{2}$ Boston Biomedical Research Institute, 64 Grove Street, Watertown, MA 02472, USA. ${ }^{3}$ Department of Cell and Developmental Biology, University of Illinois, 601 S. Goodwin Avenue, Urbana, IL 61801, USA.

Published: 18 March 2013

doi:10.1186/1756-8935-6-S1-P6

Cite this article as: Morgan et al: Association of modified cytosines and the methylated DNA-binding protein MeCP2 with distinctive structural domains of lampbrush chromatin. Epigenetics \& Chromatin 2013 6(Suppl 1):P6.
Submit your next manuscript to BioMed Central and take full advantage of:

- Convenient online submission

- Thorough peer review

- No space constraints or color figure charges

- Immediate publication on acceptance

- Inclusion in PubMed, CAS, Scopus and Google Scholar

- Research which is freely available for redistribution

Submit your manuscript at www.biomedcentral.com/submit
Biomed Central 